by the Arbitration Agreement. The report expresses regret that the staff side of the National Whitley Council has decided not to give evidence to the Priestley Commission on general pay issues, but to leave each organization to state its own views.

The outstanding question appears to be whether the Priestley Commission will give the Civil Service the long overdue examination, and its importance was stressed by the president of the Institution, Sir Richard A. S. Redmayne, in opening the annual delegate conference of the Institution on May 24. Sir Richard claimed that the Civil Service owes its position to its capacity to attract men and women of first-rate ability, and referred to the statement of the Macdonald Commission in 1914 that it was an accepted principle with all parties that the Government should be a model employer. Now, in its evidence before the Priestley Commission, the Treasury claims that the comparison should be with the current rate paid by the generality of outside employers to staff engaged on comparable work, and Sir Richard quoted evidence that, in consequence, the Civil Service is failing to obtain the recruits it requires, for example, as inspectors of mines and technical engineers. These remarks on the importance of maintaining a first-rate Civil Service were endorsed by the general secretary, Mr. S. Mayne, in presenting the annual report, who claimed that the evidence and proposals submitted by the Institution to the Royal Commission were a considered and constructive contribution, not only to the needs of the Civil Service but also to national needs. Mr. Mayne also commented on the question of civil rights, and his speech indicated the concern with which the attempt to reach a reasonable compromise between security and civil liberties in the Atomic Energy Authority Bill is being followed.

\section{Radiation-suppressing Coatings for Metals at Elevated Temperatures}

A DEscription of an investigation undertaken to develop a refractory coating of low thermal emissivity which could be applied to alloys used in gas-turbine construction and which would withstand the severe operating conditions involving thermal shock and vibration encountered in certain parts of such mechanisms is given in Special Report No. I of the Fulmer Research Institute, Ltd. (pp. 24+

plates. Stoke Poges: Fulmer Research Institute, $1953 ; 15 s$. net). The method described previously by the authors, Dr. A. H. Sully, E. A. Brandes and R. B. Waterhouse (Brit. J. App. Phys., 3, 97 ; 1952), was used to measure the emissivities of the metal surfaces of 'Nimonic 75', Vickers 'Staybright FDP' stainless steel and 'Immaculate $V$ ' in the three initial conditions-shot blasted, buffed and rolledat temperatures up to $800^{\circ} \mathrm{C}$. without prior oxidation and, after oxidation in free air, to still higher temperatures. For the refractory materials, thoria, mullite, fused silica, zircon, cordierite, aluminium titanate, alumina and magnesia, the measurements were made up to $1,300^{\circ}$ C., and the variation of emissivity with particle size, and with thickness, of refractory coatings applied to various metal surfaces was investigated. Methods of bonding the coatings and the results of fatigue, thermal shock and other tests to determine the behaviour under simulated service conditions are also described. It is shown that certain coatings, which can be applied to 'Nimonic 75', and with the use of a protective enamel undercoat also to stainless steel and to mild steel, are capable of reflecting a high proportion of incident radiation and, when correctly applied, can withstand vibration and thermal shock without loss of adhesion to the basis metal. They are potentially suitable for application to any metal parts of engines, furnaces, etc., which are undesirably heated largely by radiation.

\section{A Scholastic Flora}

Floras of well-known localized areas command not only their own special contemporary interest; they may also have future value as the landscape changes under the impact of new developments. In a small book, "Flowers and Ferns of Harrow" (Harrow School Natural History Society, 1s.), Raymond Harley, aged eighteen and still a pupil of the famous school, has attempted to record as completely as possible the flora of a country area which, like so many others, is in the course of being urbanized. This is a laudable and useful effort. It makes available to the interested inquirer, especially if he be an amateur, the botanical and common names, and the locality and time of flowering of the plants that are to be found truly wild, or as escapes, casuals, cr naturalized, in an area of historical interest. Nomenclature and general information are based on the recently published "Flora of the British Isles", by Clapham, Tutin and Warburg, and the text is illustrated by some original drawings which would do credit to a book by a more senior botanist. In the author's view, though the flora of the area is "curiously incomplete", it yet yields species of considerable interest, such as the rare alien Petasites japonicus. The author is to be congratulated on this modest but finished piece of work. It would be no bad thing, in the educational and æsthetic interest, if other schools were to emulate this interesting effort.

\section{Frotein in Developing Root Cells}

THE compositions and quantitative relations of protein and related fractions in developing bean root cells have been investigated and discussed in some detail by C. Morgan and W.S. Reith (J.Exp. Bot., 5, 119 ; 1954). The amino-acid composition and the quantitative levels of the free amino-acid, protein and peptide fractions at different distances from the root apex were examined by techniques which are described. They have found that as the cell grows there is a threefold increase in protein, a tenfold increase in free amino-acids, and a twentyfold increase in peptides. Simultaneously, the amino-acid composition of each fraction also probably changes. Further, it has been found that various fractions from the meristematic zone yield on chromatograms a variety of ninhydrin-reacting substances which have not been found in detectable amounts in extracts from other regions.

\section{Indoleacetic Acid and Sugar Absorption}

IN an investigation of the effect of indoleacetic acid on the absorption and assimilation of sucrose by carrot slices, Husein Saild and M. I. Naguib (Proc. Egypt. Acad. Sci., 8, 75 ; 1952) have observed that the inversion of sucrose was not affected by indoleacetic acid but its uptake and utilization were stimulated, as also was the respiration. Additions of indoleacetic acid stimulated the rapid depletion of the total sugar content of the carrot slices, the inference being that it was mainly utilized in the formation of soluble organic nitrogen at the expense of the nitrate-nitrogen content of the slices. 